\title{
Virulence properties and integron-associated antibiotic resistance of Klebsiella mobilis strains isolated from clinical specimens
}

\author{
Ryszard Koczura, Joanna Mokracka, Sylwia Krzymińska \\ and Adam Kaznowski
}

Correspondence

Ryszard Koczura

koczma@amu.edu.pl

Received 9 July 2010

Accepted 13 November 2010

\section{Department of Microbiology, Faculty of Biology, A. Mickiewicz University, Poznań, Poland}

\begin{abstract}
This study examined Klebsiella mobilis isolates cultured from clinical specimens for virulenceassociated properties and antibiotic resistance. The strains produced a number of siderophores, including enterobactin, aerobactin and yersiniabactin. All isolates were able to adhere to and invade epithelial cells. They had cytotoxic activity, which caused destruction of human laryngeal epithelial HEp-2 cells and evoked lysis of murine macrophage J774 cells. Analyses of HEp-2 and J774 cellular morphology and DNA fragmentation in the cells showed features typical of cells undergoing apoptosis. Some $K$. mobilis strains harboured class 1 integrons carrying the aadA1 gene encoding an aminoglycoside adenyltransferase.
\end{abstract}

\section{INTRODUCTION}

Klebsiella mobilis is an opportunistic pathogen reported to cause nosocomial infections. Strains of K. mobilis occur in water, sewage, soil and dairy products, and in the faeces of humans and animals (Grimont \& Grimont, 2005). In the literature, K. mobilis is often referred to as Enterobacter aerogenes, as it was initially included in the genus Enterobacter (Hormaeche \& Edwards, 1960). However, DNA relatedness studies (Steigerwalt et al., 1976) and numerical classification have showed that this species is closer to Klebsiella than to Enterobacter, and it was proposed that Enterobacter aerogenes was transferred to the genus Klebsiella under the name of K. mobilis (Bascomb et al., 1971).

Despite the clinical significance of $K$. mobilis strains, their pathogenic mechanisms have not been identified. They are probably multifactorial, with the involvement of a number of putative virulence factors. To multiply in infected organisms, bacteria have to acquire iron that is bound to host proteins such as transferrin, lactoferrin or ferritin. This is often carried out by siderophores, low-molecular-mass chelators that specifically bind $\mathrm{Fe}^{3+}$ outside the bacterial cell and transport it into the cytoplasm. It has been demonstrated that siderophores contribute to the virulence of a wide variety of bacterial pathogens (Wooldridge \& Williams, 1993; Lawlor et al., 2007).

In some pathogenic bacteria, colonization of the epithelial cells is followed by invasion of the underlying tissues. These

Abbreviations: 2-ME, 2-mercaptoethanol; Al, apoptosis index; ERIC, enterobacterial repetitive intergenic consensus; HPI, high-pathogenicity island; NI, necrosis index; p.i., post-infection; TTSS, type III secretion system. processes are associated with the initiation of infection and are therefore considered as essential virulence factors. After adhesion and invasion to epithelial cells, pathogenic strains may produce a number of toxins that cause the clinical manifestation of infection. Some strains produce enterotoxins, $\alpha$-haemolysin and a thiol-activated leukotoxic haemolytic toxin, which requires activation with 2mercaptoethanol (2-ME) (Barnes et al., 2001; Paraje et al., 2005).

The major defence mechanism of host non-specific immunity is cell-mediated killing. Phagocytes, either resident in tissues or circulating in blood, contribute to the primary line of innate defence against bacterial pathogens by providing their removal and destruction at the level of the epithelial barrier. Some bacterial pathogens have developed strategies for avoiding the antimicrobial effects of phagocytes and have evolved mechanisms that kill the immune cells. Some studies have attempted to define the role of apoptosis during bacterial infection. In some settings, apoptosis may contribute to bacterial virulence and pathological tissue injury, but in others, it may be of benefit to the host by enhancing the killing of the bacteria and controlling the inflammatory response (Navarre \& Zychlinsky, 2000).

In addition to the multifactorial mechanism of pathogenesis, the treatment of K. mobilis infections is often complicated by multidrug resistance. Recent focus on the spread of antibiotic resistance among pathogenic bacteria has been on integrons, genome platforms that are responsible for integration and rearrangements of resistance gene cassettes. The integrated gene cassettes are expressed and the strain thus acquires antibiotic resistance (Nemergut et al., 2008). 
In the current study, we investigated the interactions of $K$. mobilis human isolates with human epithelial cells and macrophages. We examined the adherence and invasion ability of these strains to human laryngeal epithelial (HEp2) cells, and their cytotoxic activity towards epithelial cells and murine macrophages. Moreover, we examined the apoptotic effects of K. mobilis on epithelial cells and macrophages originating from a well-established macrophages cell line, J774. Adhesion and invasion of the strains to the host cells, cytotoxic activity and the ability to induce apoptosis may be related to the development of disease. We also investigated siderophore-based iron-acquisition systems of $K$. mobilis human isolates and determined their susceptibility to antibiotics with a focus on integron-based resistance. Therefore, this study is important for revealing K. mobilis pathogenicity mechanisms essential for the establishment of infection and antimicrobial resistance crucial for survival and growth during antibiotic therapy.

\section{METHODS}

Bacterial strains. Five strains of $K$. mobilis were used in this study. The strains were isolated from samples taken from hospitalized patients: MPU E5 from faeces, MPU E10 from aspirate, MPU E61 from ulceration, and MPU E29 and MPU E36 from urine. The isolates were identified using the API 20E system (bioMérieux) and further confirmed by sequencing the $h s p 60$ gene (Morand et al., 2009). Strains were maintained at $-75{ }^{\circ} \mathrm{C}$ in brain heart infusion broth (bioMérieux) containing $50 \%(\mathrm{v} / \mathrm{v})$ glycerol.

Clonal analysis. To determine whether the isolates were genetically similar, enterobacterial repetitive intergenic consensus (ERIC)-PCR fingerprinting was applied to amplify ERIC sequences of genomic DNA. The primers used were ERIC 1 ( $5^{\prime}$-ATGTAAGCTCCTGGGGATTCAC-3') and ERIC 2 (5'-AAGTAAGTGACTGGGGTGAGCG$\left.3^{\prime}\right)$. The PCR was carried out as described by Versalovic et al. (1991). Electrophoretic patterns of the products were analysed using Gel Compar II version 3.5 software (Applied Maths) with the Dice coefficient and UPGMA method.

Siderophore production. Production of siderophores was determined in cross-feeding assays, which test the ability of bacteria to promote the growth of siderophore-deficient receptor-proficient indicator strains grown under iron starvation. Salmonella typhimurium TA 2700 (enterobactin indicator), Escherichia coli LG 1522 (aerobactin and rhodotorulic acid indicator), Aureobacterium flavescens JG-9 (indicator strain for hydroxamate siderophores distinct from aerobactin) and Morganella morganii SBK 3 (rhizoferrin and $\alpha$-keto acids indicator) were used for the detection of siderophore production (Reissbrodt \& Rabsch, 1988). In addition, Yersinia enterocolitica 5030, a strain that is unable to produce siderophores but uses exogenous yersiniabactin, was used to detect the production of yersiniabactin (Haag et al., 1993).

PCR analysis of the Yersinia high-pathogenicity island (HPI). The presence of the Yersinia HPI was determined by PCR analysis with primers targeting the irpl gene and DNA regions that encompass the asnT/int and intlybtS genes (Karch et al., 1999). The PCR conditions were as follow: $94{ }^{\circ} \mathrm{C}$ for $5 \mathrm{~min}$, followed by 30 cycles of $94{ }^{\circ} \mathrm{C}$ for $1 \mathrm{~min}, 56{ }^{\circ} \mathrm{C}$ for $1 \mathrm{~min}$ and $72{ }^{\circ} \mathrm{C}$ for $1 \mathrm{~min}$, with a final extension step at $72{ }^{\circ} \mathrm{C}$ for $5 \mathrm{~min}$ for the $\operatorname{irp} 1$ gene; $94{ }^{\circ} \mathrm{C}$ for $5 \mathrm{~min}$, followed by 30 cycles of $94{ }^{\circ} \mathrm{C}$ for $1 \mathrm{~min}, 53{ }^{\circ} \mathrm{C}$ for $1 \mathrm{~min}$ and $72{ }^{\circ} \mathrm{C}$ for $2 \mathrm{~min}$, with a final extension step at $72{ }^{\circ} \mathrm{C}$ for $8 \mathrm{~min}$ for the asn T/int region; and $94{ }^{\circ} \mathrm{C}$ for $5 \mathrm{~min}$, followed by 30 cycles of $94{ }^{\circ} \mathrm{C}$ for $1 \mathrm{~min}$, $54{ }^{\circ} \mathrm{C}$ for $1 \mathrm{~min}$ and $72{ }^{\circ} \mathrm{C}$ for $1 \mathrm{~min}$, with a final extension step at $72{ }^{\circ} \mathrm{C}$ for $5 \mathrm{~min}$ for the int $y b t S$ region. Amplification was carried out in a $25 \mu \mathrm{l}$ volume with $2.5 \mu \mathrm{l} 10 \times$ PCR buffer, $0.25 \mu \mathrm{M}$ each primer (Oligo.pl), $200 \mu \mathrm{M}$ dNTP mix, $2.5 \mathrm{mM} \mathrm{MgCl}_{2}, 0.5 \mathrm{U} \mathrm{Hi}-\mathrm{Fi}$ Taq polymerase (Novazym) and $0.5 \mu \mathrm{g}$ genomic DNA.

Cell cultures. The murine macrophage cell line J774 was maintained in RPMI 1640 (Biomed) supplemented with $10 \%$ heat-inactivated fetal calf serum (FCS) (Gibco), gentamicin $\left(5 \mu \mathrm{g} \mathrm{ml}^{-1}\right)$ and $2 \mathrm{mM} \mathrm{L}$ glutamine (Sigma). HEp-2 cells were cultured in Eagle's minimum essential medium (EMEM; Biomed) supplemented with 5\% FCS, $2 \mathrm{mM}$ glutamine, $80 \mathrm{IU}$ penicillin $\mathrm{ml}^{-1}, 80 \mu \mathrm{g}$ streptomycin $\mathrm{ml}^{-1}$ and $1 \mathrm{mg}$ nystatin $\mathrm{ml}^{-1}$. The eukaryotic cells were seeded with $100 \mu \mathrm{l}$ of a suspension of $2 \times 10^{5}$ bacterial cells per well and incubated at $37{ }^{\circ} \mathrm{C}$ in an atmosphere with $5 \% \mathrm{CO}_{2}$ (Keller et al., 1998).

Bacterial adhesion to and invasion of HEp-2 cells. Adhesion and invasion were examined in quantitative assays following a method modified from that of Keller et al. (1998). The epithelial cell monolayer was infected with bacteria at an m.o.i. of $50\left(2 \times 10^{5} \mathrm{HEp}-\right.$ 2 cells were incubated with approximately of $1 \times 10^{7}$ bacterial cells) for $2 \mathrm{~h}$. During the infection period, bacteria adhered to and invaded the HEp-2 cells. In samples where adhesion and invasion were analysed, $200 \mu \mathrm{l}$ EMEM with $2 \%$ FCS and $2 \%$ D-mannose were added for $4 \mathrm{~h}$. Associated and internalized bacteria were released by treatment with $100 \mu \mathrm{l} 0.01 \%$ Triton X-100 in PBS for 5 min at room temperature and the number of bacteria was calculated by plate counting on tryptic soy agar (Difco). For quantification of internalized bacteria, infected cells were washed in PBS and incubated with EMEM containing gentamicin $\left(100 \mu \mathrm{g} \mathrm{ml}^{-1}\right)$ for $2 \mathrm{~h}$ at $37^{\circ} \mathrm{C}$ to kill extracellular bacteria. After three washes in PBS, the cells were incubated in medium without gentamicin for $2 \mathrm{~h}$. The number of intracellular bacteria was determined by plating the lysates onto tryptic soy agar. The number of attached bacteria was determined by subtracting the number of intracellular bacteria from the total count. The results were expressed as an adhesion index, i.e. the mean number of associated bacteria per $100 \mathrm{HEp}-2$ cells. The invasion index was expressed as the percentage of the number of internalized bacteria per $100 \mathrm{HEp}-2$ cells compared with the number of adhering bacteria (Superti et al., 2005). As controls, an invasive strain of $Y$. enterocolitica $\mathrm{O}: 8 / 1 \mathrm{~B}\left(\mathrm{pYV}^{+}\right)$and non-pathogenic E. coli $\mathrm{K}-12 \mathrm{C} 600$ were included. The adhesion and invasion indices shown in Table 1 represent two independent experiments performed in triplicate.

Cytotoxic activity towards epithelial cells. The assay was performed as described by Krzymińska et al. (2009b). To prepare bacterial filtrates, bacteria were incubated in tryptic soy broth in a shaking incubator with agitation at 300 r.p.m. at $37^{\circ} \mathrm{C}$ for $18 \mathrm{~h}$. Next, $0.18 \mathrm{M}$ 2-ME was added for $30 \mathrm{~min}$ at $37{ }^{\circ} \mathrm{C}$ (Paraje et al., 2005). Cytotoxic activity was examined for filtrates from cultures grown in tryptic soy broth and those activated with 2-ME. The cultures were centrifuged at 3000 r.p.m. in a microfuge for $20 \mathrm{~min}$ and the supernatants were sterilized through $0.22 \mu \mathrm{m}$ pore size membrane filters (Millex-GV; Millipore). Twofold serial dilutions $(1: 2-1: 512)$ of culture filtrates in PBS were added to the wells of a tissue culture plate containing a confluent HEp-2 monolayer and incubated for 24 h at $37{ }^{\circ} \mathrm{C}$. As a negative control, filtrates of the nonpathogenic E. coli K-12 C600 were added. The cytotoxic titre of each isolate was calculated by determining the reciprocal of the highest dilution of culture filtrate that produced a cytopathic effect. The results were observed under an inverted microscope (Nikon Eclipse TE-2000). All tests were performed in duplicate.

Cytotoxic activity towards murine macrophage $\mathbf{J 7 7 4}$ cells in a neutral red retention assay. Neutral red is a biomarker of cellular stress as a supravital dye taken up in the lysosomes of viable cells. The 
Table 1. Adhesion, invasion and cytotoxic activity of $K$. mobilis strains

\begin{tabular}{|lcccc|}
\hline \multirow{2}{*}{ Strain } & $\mathbf{1 0}^{-\mathbf{5}} \times \mathbf{A I}^{*}$ & Invasion index $(\%) \dagger$ & \multicolumn{2}{c|}{ Cytotoxic titre } \\
\cline { 3 - 5 } & & & HEp-2 $\ddagger$ & J774\$ \\
\hline MPU E5 & $18.4 \pm 4.6$ & $13.7 \pm 4.8$ & 1 & 39 \\
MPU E10 & $4.2 \pm 0.9$ & $9.7 \pm 3.6$ & 1 & 67 \\
MPU E29 & $27.9 \pm 5.7$ & $25.3 \pm 9.1$ & 32 & 45 \\
MPU E36 & $7.9 \pm 2.7$ & $1.1 \pm 0.3$ & 1 & 48 \\
MPU E61 & $62.4 \pm 15.7$ & $15.8 \pm 7.9$ & 16 & 53 \\
E. coli K-12 C600 & $0.04 \pm 0.01$ & $0.05 \pm 0.03$ & - & - \\
Y. enterocolitica O :8/1B & $15.4 \pm 7.2$ & $40.15 \pm 11.4$ & 128 & 76 \\
\hline
\end{tabular}

${ }^{\star}$ Mean number of associated (c.f.u.) bacteria per 100 HEp-2 cells.

$\dagger$ Mean percentage of number of internalized bacteria \pm SD per 100 HEp-2 cells compared with the number of adhering bacteria from two separate experiments performed in triplicate.

$\$$ Reciprocal of the highest dilution of culture filtrate that produced a cytopathic effect.

\$Percentage of cytotoxicity was determined $24 \mathrm{~h}$ after infection by a neutral red retention assay.

assay was performed in microtitration plates as described by Carbonell et al. (1997) with slight modifications. The macrophage monolayer was incubated with bacterial culture filtrates, obtained as described above, at $37{ }^{\circ} \mathrm{C}$ for $24 \mathrm{~h}$. For negative and positive controls, the monolayers were infected with non-pathogenic E. coli K-12 C600 and invasive $Y$. enterocolitica $\mathrm{O}: 8 / 1 \mathrm{~B}$ filtrates, respectively. Next, the medium was removed and the cultures were washed with PBS, and $200 \mu \mathrm{l}$ neutral red $\left(50 \mu \mathrm{g} \mathrm{ml}^{-1}\right)$ was added to each well and incubated for $3 \mathrm{~h}$ at $37{ }^{\circ} \mathrm{C}$. After incubation, the dye solution was aspirated and the cells were rinsed in PBS before being fixed with formalin in calcium chloride solution (40\% formaldehyde, $10 \%$ anhydrous calcium chloride), which was then removed. The incorporated dye was eluted from the cells by adding ethanol/acetic acid mixture (50\% ethanol and $1 \%$ acetic acid) and the absorbance at $540 \mathrm{~nm}$ was measured using a plate reader. The absorbance was corrected against blank wells containing sterile growth medium processed as described above. Cell viability was determined by comparison with the absorbance values obtained from the blank wells (taken as $100 \%$ viability). Cytotoxic activity was calculated by subtracting the percentage of viable cells from 100 .

Assessment of apoptosis of HEp-2 and $\mathbf{J 7 7 4}$ cells. Two different methods were used for the detection of apoptotic epithelial cells and macrophages. Cell cultures were evaluated morphologically for the characteristics of apoptotic cell death. The infected cell monolayer was detached using $0.25 \%$ trypsin and $0.25 \%$ EDTA in PBS, and the suspension was stained with acridine orange $\left(100 \mu \mathrm{g} \mathrm{ml}^{-1}\right)$ and ethidium bromide $\left(100 \mu \mathrm{g} \mathrm{ml}^{-1}\right)$ (Superti et al., 2005) and examined under a Nikon Eclipse TE-2000 fluorescence microscope. Each sample was analysed in triplicate by counting at least 100 or more cells for each replicate. The cells were classified, according to the colour and structure of the chromatin, into three different groups: viable, apoptotic and necrotic cells. The percentage of apoptotic and necrotic cells, represented as apoptosis indices (AIs) and necrosis indices (NIs), were determined by counting a minimum of 100 cells selected at random from three preparations (Falcón et al., 2001). The AI and NI data are presented as means \pm SD, and represent two independent experiments performed in triplicate.

Analysis of intranucleosomal fragmentation was carried out as described previously (Krzymińska et al., 2009a). Infected cells were lysed with hypotonic buffer $[100 \mathrm{mM} \mathrm{NaCl}, 10 \mathrm{mM}$ Tris/HCl (pH 7.5), $1 \mathrm{mM}$ EDTA, $1 \%$ SDS, $200 \mathrm{mg}$ proteinase $\mathrm{K} \mathrm{ml}^{-1}$ ] for $16 \mathrm{~h}$ at $37^{\circ} \mathrm{C}$. The lysates were extracted with an equal volume of phenol: chloroform $(1: 1)$ and with an equal volume of chloroform: isoamyl alcohol $(24: 1)$ before precipitation with ethanol. The precipitates were dried, solubilized in TE buffer $[10 \mathrm{mM}$ Tris/ $\mathrm{HCl}$ ( $\mathrm{pH}$ 8.0), $1 \mathrm{mM}$ EDTA] and digested with $2 \mathrm{mg}$ RNase $\mathrm{ml}^{-1}$. Electrophoresis was performed in a $1.5 \%$ agarose gel (Basica LE GQT; Prona) at $120 \mathrm{~V}$ for $3 \mathrm{~h}$. The DNA was stained with ethidium bromide, visualized under UV light and digitalized using a Bio-Print V.99 system (Vilbert-Lourmat).

Detection of a type III secretion system (TTSS). TTSS genes were detected by PCR. Genomic DNA was isolated with a genomic mini kit (A\&A Biotechnology). We used two sets of primers (Oligo.pl): ESCV1 (5'-TAACTTCTTTCCCCACAATC-3') and ESCV2 (5'-TATCCCCAACAGGCAAAC- $3^{\prime}$ ) that target the escV gene (Kyaw et al., 2003), and ASCV-F (5'-GTAARCAGATGAGTATCGATGG-3') and ASCV-R (5'-GAGACSCGGGTGACGATAAT-3') for detection of the ascV gene (Yu et al., 2004). PCR analyses were carried out in a C1000 thermal cycler (Bio-Rad) in a $50 \mu \mathrm{l}$ volume with $1 \mu \mathrm{g}$ genomic DNA, $5 \mu \mathrm{l} 10 \times$ PCR buffer with $\mathrm{NH}_{4}\left(\mathrm{SO}_{4}\right)_{2}, 0.25 \mathrm{mM}$ each primer, $200 \mathrm{mM}$ dNTPs, $2.5 \mathrm{mM} \mathrm{MgCl}_{2}$ and $2 \mathrm{U}$ Hi-Fi Taq polymerase. The PCR products were separated in a $1.5 \%$ agarose gel.

Samples for scanning electron microscopy were prepared as described by Krzymińska et al. (2009b). Bacteria were cultured overnight in brain heart infusion with $2 \%$ agar at $37^{\circ} \mathrm{C}$. After incubation, the bacteria were harvested and suspended in PBS to a McFarland scale no. 1 and diluted 1:100 in EMEM. The bacterial suspension was incubated with a monolayer of Vero cells for $45 \mathrm{~min}$ at $37^{\circ} \mathrm{C}$ and passaged into the next well containing Vero cells. The passages were repeated four times. The bacteria were then fixed in $1 \%$ formaldehyde for $1 \mathrm{~h}$ on ice, washed in PBS and placed on a glass coverslip. The samples were fixed in $2 \%$ glutaraldehyde for $5 \mathrm{~min}$ at room temperature, washed in TE buffer and dehydrated in a series of acetone solutions. The samples were critical-point dried, coated with gold and observed under an EVO 40 (Zeiss) scanning electron microscope.

Antimicrobial susceptibility. Antibiotic resistance patterns were determined according to the standard disc diffusion method (CLSI, 2009). Isolates were tested for susceptibility to 16 antibiotics representing 8 classes: aminoglycosides, amphenicols, carbapenems, penicillins, cephalosphorins, quinolones, sulfonamides and tetracyclines. The production of extended spectrum $\beta$-lactamases was assayed by the double-disc synergy test with ceftazidime, cefotaxime 
and amoxicillin/clavulanic acid. The production of AmpC $\beta$ lactamases was checked by a three-dimensional assay with cefoxitin and E. coli ATCC 25922 as a control (Coudron et al., 2000). All antibiotic discs were from Oxoid.

Identification of integrase genes. The sequences of primers chosen were as described by Dillon et al. (2005). Primers IntIF and IntIR were used for the detection of class 1 integrase (intI1; $160 \mathrm{bp}$ product), Int2.F and Int2.R for class 2 integrase (intI2; $788 \mathrm{bp}$ product), and Int3.F and Int3.R for class 3 integrase (intI3; $979 \mathrm{bp}$ product). PCRs were performed in a $25 \mu \mathrm{l}$ volume with $2.5 \mu \mathrm{l} 10 \times$ PCR buffer with $\mathrm{NH}_{4}\left(\mathrm{SO}_{4}\right)_{2}, 0.25 \mu \mathrm{M}$ each primer (Oligo.pl), $200 \mu \mathrm{M}$ dNTP mix, $2.5 \mathrm{mM} \mathrm{MgCl}_{2}$, 2 U Taq DNA polymerase and $100 \mathrm{ng}$ genomic DNA. Amplification involved initial denaturation at $94{ }^{\circ} \mathrm{C}$ for $5 \mathrm{~min}$, followed by 30 cycles of denaturation at $94{ }^{\circ} \mathrm{C}$ for $1 \mathrm{~min}$, annealing at $59^{\circ} \mathrm{C}$ for $1 \mathrm{~min}$ and extension at $72{ }^{\circ} \mathrm{C}$ for $1 \mathrm{~min}$, with a final extension step at $72{ }^{\circ} \mathrm{C}$ for $8 \mathrm{~min}$.

Analysis of the variable region of the class 1 integron. The sequences of primers complementary to the $5^{\prime}$ and $3^{\prime}$ conserved regions have been published elsewhere (Lévesque et al., 1995). PCRs were conducted as follow: initial denaturation at $94{ }^{\circ} \mathrm{C}$ for $5 \mathrm{~min}$, followed by 30 cycles of $94{ }^{\circ} \mathrm{C}$ for $1 \mathrm{~min}, 55{ }^{\circ} \mathrm{C}$ for $1 \mathrm{~min}$ and $72{ }^{\circ} \mathrm{C}$ for $5 \mathrm{~min}$, with a final elongation at $72{ }^{\circ} \mathrm{C}$ for $8 \mathrm{~min}$. The nucleotide sequences of the amplicons were determined in a 3130xl genetic analyser (Applied Biosystems). A sequence similarity search was carried out using BLAST (http://blast.ncbi.nlm.nih.gov/Blast.cgi).

Conjugation assay. The transfer capability of integrons was determined in a conjugation assay with an E. coli J-53 (Rif ${ }^{\mathrm{R}}$ ) recipient strain in a broth mating procedure. The donor and recipient strains were cultured for $18 \mathrm{~h}$ at $30{ }^{\circ} \mathrm{C}$, mixed in a $1: 1$ ratio and incubated for $3 \mathrm{~h}$ at $37^{\circ} \mathrm{C}$. Samples $(20 \mu \mathrm{l})$ were spread on agar plates containing rifampicin and streptomycin and incubated overnight at $30{ }^{\circ} \mathrm{C}$. The presence of class 1 integrase among the transconjugants was confirmed by the multiplex PCR described above.

\section{RESULTS AND DISCUSSION}

\section{Clonal analysis}

The clonal relatedness of the strains was established by ERIC-PCR typing. The ERIC fingerprints consisted of 3 to 17 bands ranging in size from 160 to $5400 \mathrm{bp}$. All strains were genetically unrelated, with the highest similarity between two isolates reaching $52 \%$.

\section{Siderophore production}

We determined the ability of extraintestinal strains of $K$. mobilis to employ different siderophore-mediated strategies of iron acquisition. Biological assays with indicator strains deficient in siderophore synthesis but capable of acquiring exogenous iron chelators indicated that the strains excreted the catecholate siderophore enterobactin, the hydroxamate siderophore aerobactin (with the exceptions of MPU E36 and MPU E61) and hydroxamates other than aerobactin, e.g. coprogen, ferrichrome, rhodotorulic acid or ferrioxamine B. Moreover, all strains were able to cross-feed the indicator strain Y. enterocolitica 5030 for yersiniabactin production.

The genes for the yersiniabactin-mediated iron-uptake systems in Enterobacteriaceae are often located in a genomic island known as the Yersinia HPI (Bach et al., 2000). To determine whether the isolates had yersiniabactin genes located within the HPI, we carried out PCRs to find out whether the yersiniabactin operon was located in the vicinity of an integrase gene and a tRNA gene, characteristic features of pathogenicity islands. We obtained PCR products with primers specific for the irpl gene and primers targeting regions encompassing: (i) the asparaginespecific tRNA gene (asnT) and the integrase gene (int), and (ii) the int gene and the $y b t S$ gene involved in yersiniabactin biosynthesis (Karch et al., 1999). The PCR products for the irpl gene and the asnT/int and int/ybtS regions were 240, 1250 and $830 \mathrm{bp}$, respectively, which corresponded with the expected sizes.

Siderophore production contributes to bacterial virulence, as the ability to acquire iron within the host is crucial during infection. Aerobactin and yersiniabactin have been shown to be virulence factors in many bacterial species, including those from the family Enterobacteriaceae (Bach et al., 2000; Mokracka et al., 2004). Enterobactin has a higher affinity for iron than human iron-binding proteins; however, its role in bacterial virulence is not clear, as, for example, the mammalian protein siderocalin binds enterobactin, making it ineffective in bacterial iron acquisition (Nelson et al., 2007). The presence of more than one siderophore-mediated iron-acquisition system may be of benefit for $K$. mobilis strains, as different systems may function in different environments within the host or at different stages during the course of an infection (Torres et al., 2001).

Recently, it has been reported that bacterial iron chelators can activate human hypoxia-inducible factor 1 (HIF-1) during infection. HIF-1 is a key transcriptional regulator during adaptation to oxygen deprivation. Siderophores can activate HIF-1 in a manner independent of hypoxia. This has been proved for yersiniabactin and aerobactin, although currently it is not clear whether the induction of HIF-1 is beneficial or disadvantageous for the host organism (Hartmann et al., 2008).

\section{K. mobilis adhesion to and invasion of human epithelial cells}

For many pathogens, adhesion to and invasion of the host epithelial cells have been shown to be the primary steps in colonization. Adhesion to HEp-2 cells and invasion of $K$. mobilis were examined by a gentamicin survival assay. All strains were gentamicin sensitive $\left(0.1 \mathrm{mg} \mathrm{ml}^{-1}\right)$. The results of the adhesion and invasion assays are presented in Table 1. Our results demonstrated that all isolates were able to adhere to HEp-2 cells and had a higher efficiency of adhesion compared with that of the E. coli non-invasive control. The adhesion indices ranged from $4.2 \times 10^{5}$ to $62.4 \times 10^{5}$ c.f.u. per $100 \mathrm{HEp}-2$ cells. The E. coli K-12 C600 negative control had an adhesion index of $0.4 \times 10^{4}$ c.f.u., whereas the $Y$. enterocolitica $\mathrm{O}: 8 / 1 \mathrm{~B}$ positive control had an adhesion index of $15.4 \times 10^{5}$ c.f.u. $^{-1}$. 
The isolates of $K$. mobilis were able to invade Hep-2 cells. The percentage of associated bacteria that were internalized (invasion index) ranged from 9.7 to $25.3 \%$, whereas the invasion index of non-pathogenic E. coli K-12 C600 was $0.05 \%$.

\section{Cytotoxic activity}

The cytopathic effect caused by cytotoxic toxins was detected by rounding and shrinkage of the HEp-2 cells (Table 1). All strains caused this effect after treating the culture supernatant with 2-ME. Three K. mobilis strains (MPU E5, MPU E10 and MPU E36) were found to be cytotoxic to HEp-2 cells at a titre of 1 (i.e. only undiluted supernatants were cytotoxic). Isolates MPU E29 and MPU E61 were more cytotoxic, with titres of 32 and 16, respectively. All strains were cytotoxic to murine J774 cells after $24 \mathrm{~h}$ supernatant treatment, as measured by a neutral red assay (Table 1). The highest cytotoxicities (53 and $67 \%$ ) were observed for MPU E61 and MPU E10 isolates. All isolates produced cytotoxins that were activated by 2 ME. The non-pathogenic strain E. coli K-12 C600 was not cytotoxic to epithelial cells or macrophages.

According to Paraje et al. (2005), such thiol-activated toxins have the capacity to damage the membranes of erythrocytes and leukocytes. The culture supernatant of the MPU E10 strain not activated with 2-ME was cytotoxic to
HEp-2 and J774 cells. This indicated that K. mobilis can also produce cytotoxins that are not activated by 2 -ME. The results suggested that thiol-activated and 2-ME-independent cytotoxic toxins may cause destruction of the epithelial barrier and suppress the innate host immune defence.

\section{Apoptosis of HEp-2 and $\mathbf{J 7 7 4}$ cells induced by $K$. mobilis}

Induction of apoptosis is considered a putative virulence mechanism of bacterial pathogens that may cause tissue damage and facilitate further colonization. Programmed cell death has been defined by both morphological and biochemical criteria (Dockrell, 2001; Nagata, 2005). Morphological assessment of apoptosis is confirmed by staining cells with ethidium bromide and acridine orange and observation under a fluorescence microscope. Acridine orange permeates the cell membrane and stains the nuclei green. Ethidium bromide is taken up only when cytoplasmic membrane integrity is lost, and stains the nuclei red. Live cells have a normal green nucleus, those in the early stages of apoptosis have a bright green nucleus with condensed chromatin, and those in the late stages of apoptosis display condensed or fragmented orange chromatin, whereas cells that have died from necrosis have a structurally normal orange nucleus. Strains of K. mobilis provoked apoptosis of HEp-2 and J774 cells (Fig. 1), which displayed morphological changes including cell shrinkage,
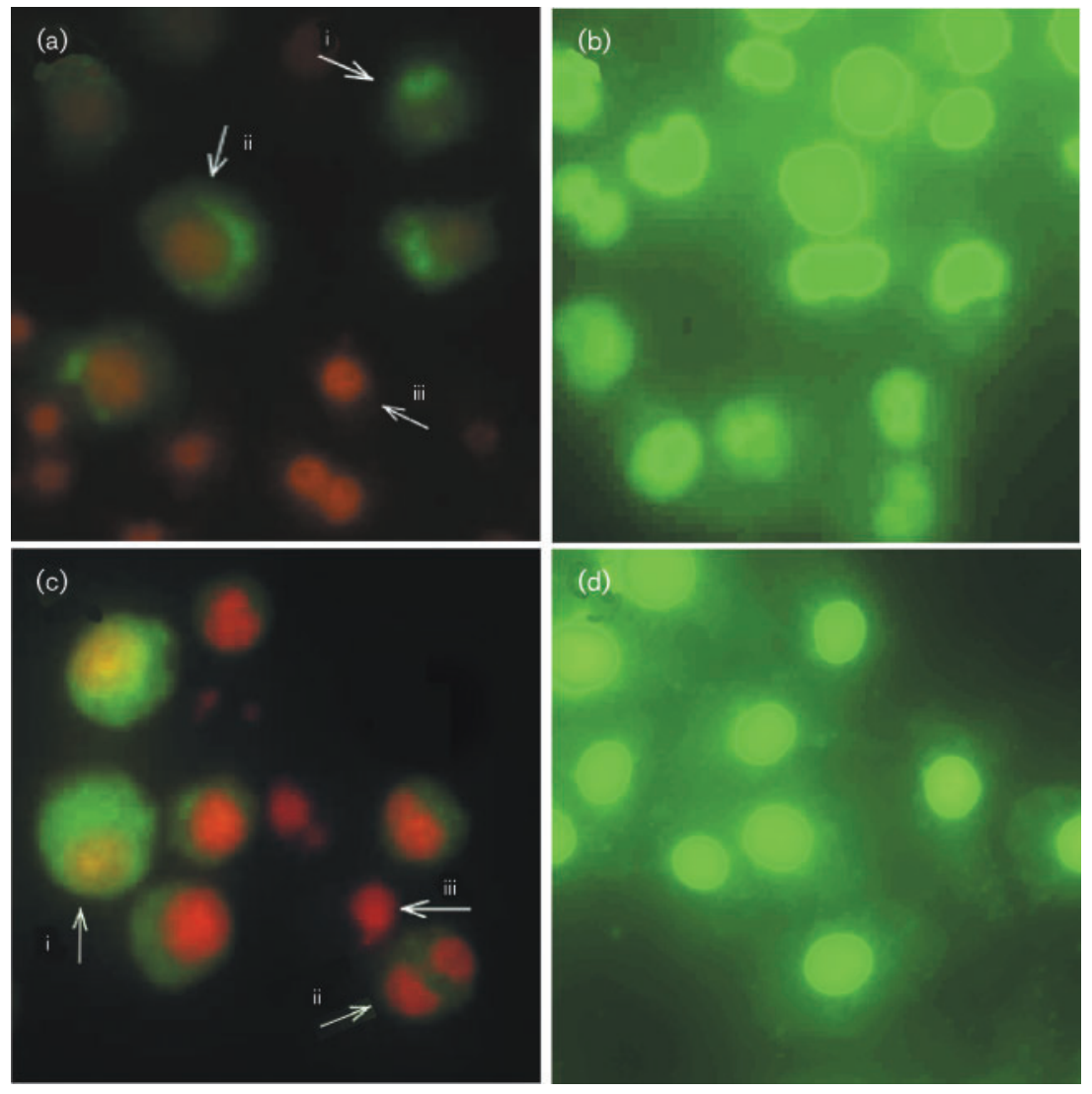

Fig. 1. Effect of $K$. mobilis on the morphology of HEp-2 and J774 cells. Cells were infected with K. mobilis $(\mathrm{a}, \mathrm{c})$ or E. coli $\mathrm{K}-12 \mathrm{C600}$ (negative control) $(b, d)$. The cells were stained with acridine orange and ethidium bromide and examined with a fluorescence microscope. Live cells had a normal green nucleus (i), apoptotic cells displayed condensed or fragmented orange chromatin (ii) and cells that had died from necrosis had a structurally normal orange nucleus (iii). Original magnifications: $\times 200(a-c) ; \times 150(d)$. 
loss of normal cell-to-cell contact and blebbing at the cell surface at 24 and $48 \mathrm{~h}$ after infection. The AIs at 24 and $48 \mathrm{~h}$ after infection are shown in Table 2. The highest AI ( $46.7 \%$ in HEp-2 cells at $24 \mathrm{~h}$ after infection) was observed for MPU E5. The remaining isolates expressed AIs ranging from 15.7 to $25.6 \%$. The percentage of apoptotic cells increased at $48 \mathrm{~h}$ post-infection (p.i.), when AIs of 58.1$77.7 \%$ were observed in HEp-2 cells infected with $K$. mobilis MPU E5, MPU E10 and MPU E61. Lower AIs were noted for strains MPU E29 and MPU E36 (32.1 and $34.1 \%$, respectively). The mean AI of the negative control was $4.5 \pm 1 \%$, whereas for the positive control it reached $84.6 \pm 5.1 \%$. All isolates induced apoptotic morphological changes in J774 cells. The percentage of apoptotic cells ranged from 6.1 to $39 \%$ at $24 \mathrm{~h}$ and was as high as $58.9 \%$ at $48 \mathrm{~h}$ after infection. The AI in J774 cells infected with non-pathogenic E. coli K-12 C600 was 5.1 $1.2 \%$.

Strains of $K$. mobilis showed also necrotic activity. HEp-2 cells at $24 \mathrm{~h}$ after infection showed an NI ranging from 7.6 to $17.2 \%$, which increased at $48 \mathrm{~h}$ to $14.5-28.4 \%$. Simi et al. (2003) partially purified a cytolytic enterotoxin from Enterobacter cloacae culture supernatant that had haemolytic activity and caused fluid accumulation in rat intestinal loops with erosive necrotic lesions.

Another feature of apoptosis is the fragmentation of DNA into multimers of 180-200 bp. Therefore, we examined $K$. mobilis induction of DNA fragmentation in epithelial cells and macrophages. Fragmentation was observed in HEp-2 cells infected with isolates MPU E5, MPU E10 and MPU E61 for 48 h. Fragmentation was also observed in J774 cells infected with $K$. mobilis MPU E10. The patterns were similar to that obtained with the positive-control $Y$. enterocolitica $\mathrm{O}: 8 / 1 \mathrm{~B}$, which induced DNA fragmentation in epithelial cells and macrophages (Fig. 2). The typical 'comet' reaction was observed when the AI exceeded $58 \%$. Strains of E. coli K-12 C200 did not induce DNA

Table 2. Al of human epithelial HEp-2 and J774 cells infected with $K$. mobilis strains at 24 and $48 \mathrm{~h}$

The AI values are the means of the percentages of apoptotic cells from two experiments performed in triplicate.

\begin{tabular}{|lcc|}
\hline Time p.i./strain & AI of HEp-2 cells (SD) & AI of J774 cells (SD) \\
\hline 24 h & & \\
MPU E5 & $46.7(4.2)$ & $6.1(0.9)$ \\
MPU E10 & $15.7(1.4)$ & $21.8(3.1)$ \\
MPU E29 & $16.4(2.1)$ & $18.5(2.3)$ \\
MPU E36 & $23.8(1.8)$ & $39.3(3.4)$ \\
MPU E61 & $25.6(3.23)$ & $31.7(2.9)$ \\
48 h & & \\
MPU E5 & $58.1(3.1)$ & $25.8(2.7)$ \\
MPU E10 & $71.7(4.9)$ & $58.9(7.8)$ \\
MPU E29 & $32.1(3.8)$ & $35.7(3.1)$ \\
MPU E36 & $34.1(4.8)$ & $57.1(5.5)$ \\
MPU E61 & $77.1(6.7)$ & $41.7(4.1)$ \\
\hline
\end{tabular}

fragmentation in HEp-2 and J774 cells at 24 and $48 \mathrm{~h}$ p.i. Barnes et al. (2001) suggested that a high concentration of the thiol-activated enterotoxins produced by Enterobacter cloacae strains increases the production of reactive oxygen species, which would contribute to toxin-induced inflammation and lysis of leukocytes before triggering apoptosis. Moss et al. (2000) reported that Bordetella pertussis kills macrophages and epithelial cells by apoptosis by secreting adenylate cyclase-haemolysin toxin, which increases cAMP levels. An increase in the intracellular concentration of cAMP leads to apoptosis of host cells.

\section{Absence of a TTSS}

Many Gram-negative pathogenic bacteria, including members of the family Enterobacteriaceae, have evolved a TTSS that enables translocation of their proteins into the cells of the infected host. There is no information, however, about a TTSS in K. mobilis or other members of this genus. To search for a TTSS, we used two sets of primers targeting $e s c V$ and $a s c V$. The esc $V$ gene codes for an inner-membrane protein that is a part of the TTSS apparatus in E. coli (Gauthier et al., 2003). Homologues of escV have been also described in strains of other genera of the Enterobacteriaceae (Plano et al., 1991; Kubori et al., 2000). The asc $V$ gene encodes a protein involved in the TTSS in Aeromonas spp. Recently, we reported a TTSS system with a gene showing a high similarity to $a s c V$ in Enterobacter cloacae (Krzymińska et al., 2009b).

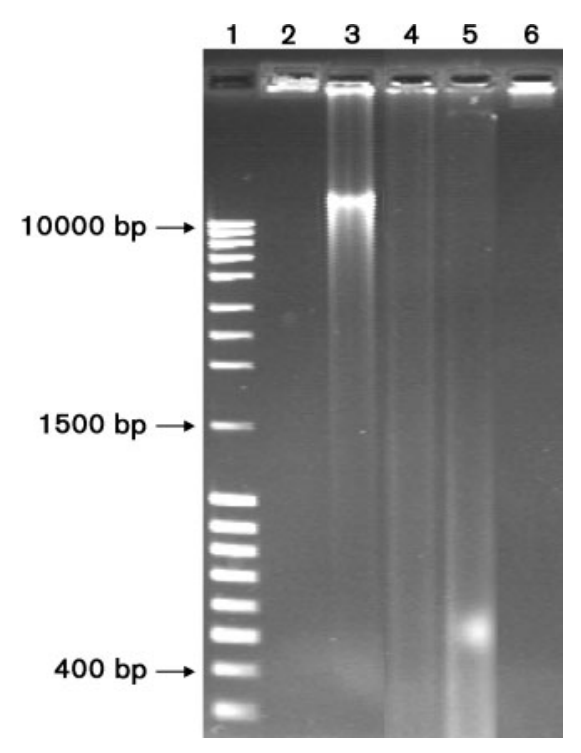

Fig. 2. Intranucleosomal breakdown of DNA from HEp-2 and J774 cells infected with $K$. mobilis. Lanes: 1 , molecular size marker; 2 , DNA extracted from HEp-2 cells infected with MPU E61 at $24 \mathrm{~h}$; 3, DNA from HEp-2 cells infected with MPU E61 at 48 h; 4, DNA from $J 774$ cells infected with MPU E10 at 48 h; 5, DNA from HEp2 cells infected with $Y$. enterocolitica O :8/1B at 24 h; $6, \mathrm{HEp}-2$ cells infected with non-pathogenic E. coli K-12 C600 at $48 \mathrm{~h}$. 
Table 3. Integrons and antibiotic resistance profiles of $K$. mobilis isolates and transconjugant strains

\begin{tabular}{|lccll|}
\hline Strain & $\begin{array}{c}\text { Class I } \\
\text { integron }\end{array}$ & $\begin{array}{c}\text { Gene } \\
\text { cassette }\end{array}$ & \multicolumn{1}{c|}{ Antibiotic resistance profile } & \multicolumn{1}{c|}{$\begin{array}{c}\text { Antibiotic resistance profile of } \\
\text { transconjugant strain }\end{array}$} \\
\hline MPU 5E & + & aadA1 & $\begin{array}{l}\text { STR, SPT, NET, CHL, TIC, PIP, TZP, } \\
\text { CTR, SUL }\end{array}$ & $\begin{array}{c}\text { STR, SPT, NET, CHL, TIC, PIP, TZP, } \\
\text { CTR, SUL, RIF }\end{array}$ \\
MPU 10E & - & NA & SUL & NA \\
MPU 29E & + & aadA1 & STR, SPT, CHL, TIC, CIP, SUL & STR, SPT, CHL, TIC, SUL, RIF \\
MPU 36E & - & NA & SUL & NA \\
MPU 61E & - & NA & SUL & NA \\
\hline
\end{tabular}

CHL, Chloramphenicol; CIP, ciprofloxacin; CTR, co-trimoxazole; NA, not applicable; NET, netilmicin; PIP, piperacillin; RIF, rifampicin; SPT, spectinomycin; STR, streptomycin; SUL, sulfamethoxazole; TIC, ticarcillin; TZP, piperacillin + tazobactam.

${ }^{*}$ The recipient strain E. coli J-53 is resistant to rifampicin.

In this study, none of the isolates of $K$. mobilis gave specific PCR products for either gene. Moreover, the cells of $K$. mobilis grown in conditions supporting the expression of a TTSS (Krzymińska et al., 2009b) and examined under a scanning electron microscope did not exhibit any surface structures resembling the needle complex of a TTSS.

\section{Integrons and antibiotic resistance}

K. mobilis strains are naturally resistant to ampicillin, cefalotin and cefoxitin (Grimont \& Grimont, 2005). The resistance to other antibiotics may be associated with integrons, which are defined as a natural gene-capture system that contain an integrase gene able to incorporate gene cassettes conferring resistance to antimicrobials. Moreover, integrons are located within mobile genetic elements such as transposons and plasmids, and can be transferred between cells of the same or different species in one genetic event, leading to resistance in bacterial strains that were previously susceptible (Mazel, 2006).

Among the five strains of $K$. mobilis, two yielded a PCR product of $160 \mathrm{bp}$ corresponding to the intI1 gene. These strains were isolated from a rectal swab (MPU 5E) and from urine (MPU 29E). In both cases, the integron-positive strains had multiple antibiotic resistance, defined as resistance to at least three unrelated antibiotics (Table 3). None of the strains produced extended spectrum $\beta$-lactamases or AmpC.

The products of PCR analyses of the variable region of class 1 integrons were both $1000 \mathrm{bp}$ in size and contained a single gene cassette. In both cases, the sequence analysis identified the aadA1 gene, which encodes aminoglycoside adenyltransferase conferring resistance to streptomycin and spectinomycin. Thus, the integrons of the clinical $K$. mobilis strains investigated here differed from those described previously that contained $a a c\left(6^{\prime}\right)-I b$, qacF, cmlA2 and oxa-9 genes (Ploy et al., 1998), $d f r V$ and ereA2 (Peters et al., 2001), aac(6')-Ib (Machado et al., 2007) or $d f r A 2 d$ (Frank et al., 2007) within their variable regions.

The integron-positive isolates were checked for rifampicin susceptibility and subjected to a broth mating experiment with a recipient strain. Both integrons were transferable to E. coli $\mathrm{J}-53\left(\mathrm{Rif}^{\mathrm{R}}\right)$ in the conjugation assay. As a consequence, the recipient strain acquired both the integron and antimicrobial resistance (Table 3 ), indicating that $K$. mobilis strains can transfer antibiotic resistance genes at least among some members of the same family.

In summary, our study describes a comprehensive evaluation of virulence factors and antibiotic resistance of clinical isolates of $K$. mobilis. The data suggest that adhesion to epithelial cells and invasion by $K$. mobilis induce apoptotic cell death. The process may primarily be a strategy developed by the strains, resulting in tissue destruction and bacterial spread, consequently leading to invasive disease or systemic infection. Strains of K. mobilis are able to employ a variety of siderophore-mediated ironacquisition systems, which allows them to replicate inside the infected host. Moreover, they can harbour integrons in their genomes and are able to spread antibiotic resistance among closely related species.

\section{REFERENCES}

Bach, S., de Almeida, A. \& Carniel, E. (2000). The Yersinia highpathogenicity island is present in different members of the family Enterobacteriaceae. FEMS Microbiol Lett 183, 289-294.

Barnes, A. I., Paraje, M. G., del C. Battán, P. \& Albesa, I. (2001). Molecular properties and metabolic effect on blood cells produced by a new toxin of Enterobacter cloacae. Cell Biol Toxicol 17, 409-418.

Bascomb, S., Lapage, S. P., Willcox, W. R. \& Curtis, M. A. (1971). Numerical classification of the tribe Klebsielleae. J Gen Microbiol 66, 279-295.

Carbonell, G. V., Alfieri, A. F., Alfieri, A. A., Vidotto, M. C., Levy, C. E., Darini, A. L. C. \& Yanaguita, R. M. (1997). Detection of cytotoxic activity on Vero cells in clinical isolates of Serratia marcescens. Braz J Med Biol Res 30, 1291-1298.

CLSI (2009). Performance Standards for Antimicrobial Disk Susceptibility Tests, 10th edn, approved standard M02-A10. Wayne, PA: Clinical and Laboratory Standards Institute.

Coudron, P. E., Moland, E. S. \& Thomson, K. S. (2000). Occurrence and detection of AmpC $\beta$-lactamases among Escherichia coli, Klebsiella pneumoniae, and Proteus mirabilis isolates at a Veterans Medical Center. J Clin Microbiol 38, 1791-1796. 
Dillon, B., Thomas, L., Mohmand, G., Zelynski, A. \& Iredell, J. (2005). Multiplex PCR for screening of integrons in bacterial lysates. J Microbiol Methods 62, 221-232.

Dockrell, D. H. (2001). Apoptotic cell death in the pathogenesis of infectious diseases. J Infect 42, 227-234.

Falcón, R. M., Carvalho, H. F., Joazeiro, P. P., Viccari Gatti, M. S. \& Yano, T. (2001). Induction of apoptosis in HT29 human intestinal epithelial cells by the cytotoxic enterotoxin of Aeromonas hydrophila. Biochem Cell Biol 79, 525-531.

Frank, T., Gautier, V., Talarmin, A., Bercion, R. \& Arlet, G. (2007). Characterization of sulphonamide resistance genes and class 1 integron gene cassettes in Enterobacteriaceae, Central African Republic (CAR). J Antimicrob Chemother 59, 742-745.

Gauthier, A., Puente, J. L. \& Finlay, B. B. (2003). Secretin of the enteropathogenic Escherichia coli type III secretion system requires components of the type III apparatus for assembly and localization. Infect Immun 71, 3310-3319.

Grimont, P. A. D. \& Grimont, F. (2005). Genus Klebsiella. In Bergey's Manual of Systematic Bacteriology, vol. 2, pp. 685-693. Edited by D. J. Brenner, N. R. Krieg \& J. T. Staley. New York: Springer.

Haag, H., Hantke, K., Drechsel, H., Stojiljkovic, I., Jung, G. \& Zähner, H. (1993). Purification of yersiniabactin: a siderophore and possible virulence factor of Yersinia enterocolitica. J Gen Microbiol 139, 2159-2165.

Hartmann, H., Eltzschig, H. K., Wurz, H., Hantke, K., Rakin, A., Yazdi, A. S., Matteoli, G., Bohn, E., Autenrieth, I. B. \& other authors (2008). Hypoxia-independent activation of HIF-1 by Enterobacteriaceae and their siderophores. Gastroenterology 134, 756-767.

Hormaeche, E. \& Edwards, P. R. (1960). A proposed genus Enterobacter. Int Bull Bacteriol Nomencl Taxon 10, 71-74.

Karch, H., Schubert, S., Zhang, D., Zhang, W., Schmidt, H., Ölschläger, T. \& Hacker, J. (1999). A genomic island, termed highpathogenicity island, is present in certain non-O157 Shiga toxinproducing Escherichia coli clonal lineages. Infect Immun 67, 5994-6001.

Keller, R., Pedroso, M. Z., Ritchmann, R. \& Silva, R. M. (1998). Occurrence of virulence-associated properties in Enterobacter cloacae. Infect Immun 66, 645-649.

Krzymińska, S., Kaznowski, A. \& Chodysz, M. (2009a). Aeromonas spp. human isolates induce apoptosis of murine macrophages. Curr Microbiol 58, 252-257.

Krzymińska, S., Mokracka, J., Koczura, R. \& Kaznowski, A. (2009b). Cytotoxic activity of Enterobacter cloacae isolates. FEMS Immunol Med Microbiol 56, 248-252.

Kubori, T., Sukhan, A., Aizawa, S.-I. \& Galán, J. E. (2000). Molecular characterization and assembly of the needle complex of the Salmonella typhimurium type III protein secretion system. Proc Natl Acad Sci U S A 97, 10225-10230.

Kyaw, C. M., De Araujo, C. R., Lima, M. R., Gondim, E. G., Brígido, M. M. \& Giugliano, L. G. (2003). Evidence for the presence of a type III secretion system in diffusely adhering Escherichia coli (DAEC). Infect Genet Evol 3, 111-117.

Lawlor, M. S., O'Connor, C. \& Miller, V. L. (2007). Yersiniabactin is a virulence factor for Klebsiella pneumoniae during pulmonary infection. Infect Immun 75, 1463-1472.

Lévesque, C., Piché, L., Larose, C. \& Roy, P. H. (1995). PCR mapping of integrons reveals several novel combinations of resistance genes. Antimicrob Agents Chemother 39, 185-191.

Machado, E., Ferreira, J., Novais, A., Peixe, L., Cantón, R., Baquero, F. \& Coque, T. M. (2007). Preservation of integron types among Enterobacteriaceae producing extended-spectrum $\beta$-lactamases in a Spanish hospital over a 15-year period (1988-2003). Antimicrob Agents Chemother 51, 2201-2204.
Mazel, D. (2006). Integrons: agents of bacterial evolution. Nat Rev Microbiol 4, 608-620.

Mokracka, J., Koczura, R. \& Kaznowski, A. (2004). Yersiniabactin and other siderophores produced by clinical isolates of Enterobacter spp. and Citrobacter spp. FEMS Immunol Med Microbiol 40, 51-55.

Morand, P. C., Billoet, A., Rottman, A., Sivadon-Tardy, V., Eyrolle, L., Jeanne, L., Tazi, A., Anract, P., Courpied, J.-P. \& other authors (2009). Specific distribution within Enterobacter cloacae complex of strains isolated from infected orthopedic implants. J Clin Microbiol 47, 2489-2495.

Moss, J. E., Idanpaan-Heikkila, I. \& Zychlinsky, A. (2000). Induction of apoptosis by microbial pathogens. In Cellular Microbiology, pp. 409-423. Edited by P. Cossard, P. Bouquet, S. Normark \& R. Rappuoli. Washington, DC: American Society for Microbiology.

Nagata, S. (2005). DNA degradation in development and programmed cell death. Annu Rev Immunol 23, 853-875.

Navarre, W. W. \& Zychlinsky, A. (2000). A pathogen-induced apoptosis of macrophages: a common end for different pathogenic strategies. Cell Microbiol 2, 265-273.

Nelson, A. L., Ratner, A., Barasch, J. \& Weiser, J. N. (2007). Interleukin-8 secretion in response to aferric enterobactin is potentiated by siderocalin. Infect Immun 75, 3160-3168.

Nemergut, D. R., Robeson, M. S., Kysela, R. F., Martin, A. P., Schmidt, S. K. \& Knight, R. (2008). Insights and interferences about integron evolution from genomic data. BMC Genomics 9, 261-272.

Paraje, M. G., Barnes, A. I. \& Albesa, I. (2005). An Enterobacter cloacae toxin able to generate oxidative stress and to provoke dose-dependent lysis of leucocytes. Int J Med Microbiol 295, 109-116.

Peters, E. D. J., Leverstein-van Hall, M. A., Box, A. T. A., Verhoeff, J. \& Fluit, A. C. (2001). Novel gene cassettes and integrons. Antimicrob Agents Chemother 45, 2961-2964.

Plano, G. V., Barve, S. S. \& Straley, S. C. (1991). LcrD, a membranebound regulator of the Yersinia pestis low-calcium response. J Bacteriol 173, 7293-7303.

Ploy, M. C., Courvalin, P. \& Lambert, T. (1998). Characterization of In 40 of Enterobacter cloacae BM2688, a class 1 integron with two new gene cassettes cmlA2 and qacF. Antimicrob Agents Chemother 42, 2557-2563.

Reissbrodt, R. \& Rabsch, W. (1988). Further differentiation of Enterobacteriaceae by means of siderophore-pattern analysis. Zentralbl Bakteriol Mikrobiol Hyg A 268, 306-317.

Simi, S., Carbonell, G. V., Falcon, R. M., Gatti, M. S. V., Joazeiro, P. P., Darini, A. L. \& Yano, T. (2003). A low molecular weight enterotoxic hemolysin from clinical Enterobacter cloacae. Can J Microbiol 49, 479-482.

Steigerwalt, A. G., Fanning, G. R., Fife-Asbury, M. A. \& Brenner, D. J. (1976). DNA relatedness among species of Enterobacter and Serratia. Can J Microbiol 22, 121-137.

Superti, F., Pietrantoni, A., Di Base, A. M., Longhi, C., Valenti, P. \& Tinari, A. (2005). Inv-mediated apoptosis of epithelial cells infected with enteropathogenic Yersinia: a protective effect of lactoferrin. Res Microbiol 156, 728-737.

Torres, A. G., Redford, P., Welch, R. A. \& Payne, S. M. (2001). TonBdependent systems of uropathogenic Escherichia coli: aerobactin and heme transport and TonB are required for virulence in the mouse. Infect Immun 69, 6179-6185.

Versalovic, J., Koeuth, T. \& Lupski, J. R. (1991). Distribution of repetitive DNA sequences in eubacteria and application to fingerprinting of bacterial genomes. Nucleic Acids Res 19, 6823-6831.

Wooldridge, K. G. \& Williams, P. H. (1993). Iron uptake mechanisms of pathogenic bacteria. FEMS Microbiol Rev 12, 325-348.

Yu, H. B., Srinivasa Rao, P. S., Lee, H. C., Vilches, S., Merino, S., Tomas, J. M. \& Leung, K. Y. (2004). A type III secretion system is required for Aeromonas hydrophila AH-1 pathogenesis. Infect Immun 72, 1248-1256. 